\title{
Otherwise than Hospitality: A Disputation on the Relation of Ethics to Law and Politics
}

\author{
Gilbert Leung and Matthew Stone*
}

In his later political writings, Derrida focused much on the ethical and political question of alterity and is well known for his political interventions on behalf of the sans-papiers in France. These interventions were guided in particular by an ethics of hospitality which he developed through a progressive reading of Kant with Levinas. In an interview in Le Monde, Derrida tantalisingly suggests that hospitality is ultimately 'an art and a poetics, yet a whole politics depends on it and a whole ethics is determined through it' (Derrida 1997a [Our Translation]).

In this essay, we would like to consider a potential critique of Derrida's application of an ethics of hospitality to a politics. Given that this project started as a debate between the authors at the 2007 Critical Legal Conference, it seemed appropriate that the style of the essay should follow the excitement of a dialectic that is quasi-Socratic in form. In section one, we give an overview of Derrida's notion of hospitality and then proceed in section two to critique the ontological violence in hospitality through the positing of an other who rejects hospitality. For this other, we ask why we should pursue hospitality on a political level when it would be far less violent to not offer hospitality in the first place. The third section serves as a counter-critique or self-critique which focuses on the nature of the relation between ethics and politics and the distinction between conceiving the other as either transcendent or transimmanent. The concluding section tangentially expands on this by looking at the violence endured and the kind of hospitality proffered

G. Leung, Birkbeck, University of London;

M. Stone, London Metropolitan University. 
in order for this essay to come before you as a joint collaboration between two authors using the first person plural and which ends with one 'dissensual' signature.

\section{DERRIDA AND HOSPITALITY}

Derrida's thinking on hospitality stems from the currently very active debate on the question of cosmopolitanism. Cosmopolitanism (kosmos: world or universe / polis: city / politēs: citizen) as the idea of world citizenship has an ancient heritage. The dominant strain of cosmopolitan thinking is based on the idea of human unity within a global community. This has given rise to various theories of centralized global governance applying cosmopolitan law in the interests of the universal citizen as opposed to international law whose primary legal actors are States. The main inspiration for this kind of thinking is traditionally credited to Kant who was interested in advancing the cause of human progress by working out the best form of global structure that would eliminate the threat of war. He concluded that the world should consist of a pacific federation of States not bound by contingent agreement (international law of treaties) but by cosmopolitan right, thus turning each individual into a 'citizen of a universal state of mankind' (Kant 1970, 99). While an international State of a world republic was considered desirable insofar as it extricated mankind from the savagery of an international arena that subsisted in a war-like state of nature, Kant was also mindful of the sacredness of the sovereign will of the nation State and its right not to be coerced into entering any such world republic. The compromise was to limit cosmopolitan right to the condition of universal hospitality, meaning 'the right of the stranger not to be treated with hostility when he arrives on someone else's territory' (ibid, 105).

Derrida draws inspiration from this notion of hospitality and derives from it a significant body of political and ethical thought that goes beyond orthodox cosmopolitanism. For Derrida, unconditional or pure hospitality is the absolute welcoming of the other, a categorical imperative that says, "yes to who or what turns up, before any anticipation, before any identification, whether or not it has to do with a foreigner, an immigrant, an 
invited guest, or an unexpected visitor, whether or not the new arrival is a citizen of another country, a human, animal, or divine creature, a living or dead thing, male or female' (Derrida 2000, 77). At the same time, Derrida draws our attention to two limits to universal hospitality that Kant himself imposed in virtue of the fact that the surface of the earth is a limited space which must be held in common possession, that is to say, "no one can in principle, therefore, legitimately appropriate for himself the aforementioned surface (as such, as a surface-area) and withhold access to another man' (Derrida 2001, 20). The first limit to universal hospitality is its exclusion of the right to residence. Hospitality only goes so far as the right of visitation, the right to present oneself to another. The second limit to hospitality is its dependence on state sovereignty: 'hospitality signifies here the public nature (publicité) of public space, as is always the case for the juridical in the Kantian sense; hospitality, whether public or private, is dependent on and controlled by the law and the state police' (ibid). Both conditional and unconditional hospitality are paradoxical imperatives. Conditional hospitality is not 'true' hospitality because it is given only on expectation of a return or offered out of decorum and therefore without responsibility. Unconditional hospitality, which is the 'truest' hospitality, is at the same time impossible because in practice one can always be more generous, more welcoming and give more of oneself and one's home until there is complete self-effacement. Hospitality subsists somewhere between certain finite conditions and the purely unconditional. Although conditional and unconditional hospitality work in tension with each other, this does not mean hospitality is selfdefeating, caught unproductively up a blind alley. On the contrary, this tension constitutes the properly political dimension of hospitality:

It is a question of knowing how to transform and improve the law, and of knowing if this improvement is possible within an historical space which takes place between the Law of an unconditional hospitality, offered a priori to every other, to all newcomers, whoever they may be, and the conditional laws of a right to hospitality, without which The unconditional Law of hospitality would be in danger of remaining a pious and irresponsible desire, without form and without potency, and of even being perverted at any moment. (ibid, 22-23). 
Whether the law of hospitality can be definitively improved or whether improvement is always something yet to be done is a question of the negotiation between universal and particular demands. While the idea of negotiating between conditional and unconditional hospitality can certainly produce outcomes, this does not mean it can provide ultimate solutions. The inherent tension guarantees there are no final solutions and any act of hospitality, in some way, always leaves itself open to a certain risk. Exposing oneself to the other, to difference, risks turning into an interrogation, aggressive self-protection and the guarding of the borders of the State as well as one's sense of identity. Moreover, since the negotiation occurs between two antinomic imperatives, the tension between them means that hospitality can easily cross over into hostility. John Caputo notes from one of Derrida's unpublished seminars that this tension is also revealed etymologically: 'The word "hospitality" derives from the Latin hospes, which is formed from hostis, which originally meant a "stranger" and came to take on the meaning of the enemy or "hostile" stranger (hostilis), + pets (potis, potes, potentia), to have power' (Caputo 1997, 110). Any act of hospitality contains within it a trace of hostility, 'the welcome of the guest, is a function of the power of the host to remain master of the premises' (ibid). Moreover, within the notion of the 'host' there is also the idea of the 'hostage'. In retaining the sovereign power to lay down the conditions of hospitality, the host in effect keeps his guest hostage to his preconditions, a prisoner of their encounter. Even within pure hospitality lies a trace of the hostage. If one relinquishes sovereignty over the home and bids the other to "come inside", "come with me", not only toward me, but within me: occupy me, take place in me, which means, by the same token, also take my place, don't content yourself with coming to meet me or "into my home", then what happens is a paradoxical substitution of host and hostage (Derrida 2000, 123). It would be as if the master waiting by the door for his guest is in fact the hostage of his own power, a prisoner of his own domain, a victim of his own subjectivity. He thus awaits the liberator and the substitution occurs, the hostage becomes the host. But if the host becomes the hostage, and the former hostage (i.e. the guest) becomes the host, an infinite cycle takes place wherein the positions of both host and hostage are simultaneously assumed. Derrida concludes, "these substitutions make everyone into everyone else's hostage" (ibid, 124). 
Equally it might be said that these substitutions make everyone into everyone else's host. As a host we contain something of the stranger, the guest and even, fleetingly, necessarily, substitute ourselves for the other at the point of pure hospitality. Derrida focuses instead on a structural impossibility that is itself the aporetic condition of the possible. Absolute hospitality is absolutely impossible, yet without it there is no hospitality and thus no cosmopolitanism.

Derrida therefore does not criticize Kant for limiting universal hospitality. On the contrary, he sees nothing fortuitous in "the one who destroys at its source the very possibility of what he posits and determines in this way" (ibid, 71). For Kant the guest is always a foreigner and sets up his relationship to him as a matter of law. Derrida concurs and draws from this the limit of hospitality that must operate everywhere, that is to say, the necessity of a border that operates as a line behind which to negotiate with the other (in State terms this border acts as the natural control point of the flow of immigration) (Derrida 1999, 90). At the same time, Derrida reinterprets the Kantian necessity for conditional hospitality within a framework that does not simply posit legal rights of visitation but that constitutes the political tension and the (in)justice of the decision between conditional and unconditional hospitality. This is why Derrida avers that deconstruction is hospitality: 'Hospitality is the deconstruction of the at-home; deconstruction is hospitality to the other, to the other than oneself, the other that its "other," to an other that is beyond any "its other" ' (Derrida 2002, 364). Instead of the nihilistic, apolitical and irresponsible practice with which it is sometimes charged, deconstruction is the affirmation of life, a responsible reflection and welcoming of the other that amounts to nothing less than an originary ethics.

The clear parallel is with Derrida's other famous pair of binary imperatives: law and justice. In his seminal essay 'The Force of Law: The Mystical Foundations of Authority', Derrida states unequivocally, 'deconstruction is justice' (ibid, 243). He distinguishes the exercise of justice as 'law, legitimacy or legality, a stabilizable, statutory and calculable apparatus, a system of regulated and coded prescriptions' from justice as 'infinite, incalculable, rebellious to rule and foreign to symmetry, heterogeneous and heterotropic' 
(ibid, 250), that is, justice as the 'experience of the impossible' (ibid, 244). Law is to justice as conditional hospitality is to pure hospitality. If pure justice and pure hospitality are experiences of the impossible, then it is precisely this impossibility that leaves open the call to justice and the need for hospitality. Crucially and at the same time, the impossibility of a fully just law and the impossibility of ever achieving pure hospitality means there will always be the unavoidable injustice of inhospitality that is the structural violence of the encounter with the other.

It is not, however, simply the case that that we are left abandoned to the injustice of inhospitality, with no further recourse than to play out our responsibility to the other through a response to the call of pure hospitality. Since hospitality is in fact always a failure of hospitality - a hostile violence in the substitution between host and guestthere is also always at play a scene of forgiveness. Not only must the host forgive the guest his encroachment in order for there to be a welcoming, the host must beg forgiveness of the guest for his failure and for his violence in never being welcoming enough. To welcome the other is never to be ready for the other and to always be surprised by the other since the other is by definition unforeseeable, unknown, and strange. 'I am always, if I can say so, always and structurally, lacking, at fault, and therefore condemned to be forgiven, or rather to have to ask for forgiveness for my lack of preparation, for an irreducible and constitutive unpreparedness' (ibid, 381). Yet forgiveness, like decision, operates on a plane of mad hyperbole. For there to be true forgiveness, there must be the impossible forgiving of the unforgivable, just like for there to be responsible decision, there must be the experience of the undecidable. Moreover, one can never offer forgiveness, for this presumes the 'haughty' power to pardon that reintroduces a sovereign act of violence (ibid, 389). Instead one must beg forgiveness in cognizance of what Heidegger termed the 'debt' or 'guilt' (schuldig) that corresponds to the originary lack in being (Dasein) insofar as it never possesses itself in virtue of its 'thrownness' (ibid, 383). Conversely, the one who forgives must do the impossible- - he or she must forgive the unforgivable fact of one's existence with others. This is an aporetic act that must both be expressed yet also remain silent. It must be expressed 
because forgiveness means nothing unless it is known and it must remain silent because any expression of it risks driving it back into the economy of a gift that is offered in expectation of a grateful return (ibid, 399). Ultimately, hospitality and the forgiveness of its violence can only be fully experienced as a mad test or ordeal within the power relation between host and guest. For Derrida, what remains to be thought, indeed what remains hopeful in this thought, is the possibility of the disassociation of unconditionality from sovereignty that is the possibility of 'forgiveness without power' (Derrida 2001, $59)$.

\section{A CRITIQUe of Hospitality}

We have already intimated that Derrida's hospitality may represent an 'originary ethics'. By 'ethics' we do not here refer to a moral code, as if one had the choice one way or another. Rather, as originary, these ethics are a pre-political aspect of the human condition. In venturing a critique now, what we are specifically concerned with is the manner in which the difference between ethical hospitality and political hospitality reveals a challenge for the notion of hospitality as such, exemplarily drawn out when it comes to particular categories of recipients.

Hospitality as an originary ethics is a concept that was clearly influenced by Derrida's friend, Emmanuel Levinas. (For instance, Derrida's essay, 'A Word of Welcome', in the eulogistic volume Adieu to Emmanuel Levinas, enthusiastically reads Levinas' Totality and Infinity to be nothing short of an 'immense treatise of hospitality' (Derrida 1999, 21)) Therefore, a brief digression into Levinas' philosophy will allow us to understand better how and why hospitality is described as 'ethical', and why sensitivity to the ethics/politics distinction is important. His philosophy was born out of a critique of Martin Heidegger, whose well known revolutionary intellectual manoeuvre was to reduce the question of metaphysics to a question of Being. Such an inquiry, known as 'ontology', identifies the human subject to be always-already thrown into a situation of the world's Being. Authentic subjectivity (Dasein) is that which questions its own Being in world. As thrown into its worldly situation, the subject already has a 'pre-ontological' 
sense of its Being, this being the condition of the ontological enquiry, and it is precisely the irreducibly circular temporality of this relation that famously introduces time into Heidegger's proposition. ${ }^{\dagger}$ Levinas' critique is to disagree with Heidegger's idea that freedom and authenticity are found in Being itself. For Levinas, ontology is falsely dependent on the totality of Being: its lack of an outside, or an other. On the contrary, he argues, freedom and authenticity are not found in the inquiry into what merely is. Rather, the human subject aspires to the what-is-not, that which is 'otherwise than Being'. Constitutive of our subjectivity is the desire to escape Being, which is characterised as burdensome, as if one's 'thrownness' into the world indicates the very nature of one's enchainment to oneself and to existence itself. Against the Heideggerian position, then, Totality and Infinity argues that subjectivity is fundamentally welcoming to the other. Levinas poses the subject that emerges from the Being of the world using the metaphor of the dwelling: a structure that can close itself off from the world in order to be for-itself, yet is at the same time inherently open and hospitable (Levinas 1969, 148). This is justified by his exposition of the encounter with the other person revealing a different dynamic to inhabitation and possession, by calling its absoluteness into question: 'The Other - the absolutely other-paralyzes possession, which he contests by his epiphany in the face' (ibid, 171). As the dwelling is the site of ontology, where the being's Being in the world produces meaning by allowing possession, this is shattered by the other's contestation of ownership. Totality is broken by the non-totalisable Infinity that the other embodies, demanding of the subject a non-violent approach that welcomes them, without assimilation or reduction. This command of non-violence is the basis of ethics (ibid, 199200).

This digression allows us to postulate the idea that ethics is not reducible to morality, law or politics, but is anteriorly embedded at the heart of the human condition. The ethical welcome occurs prior to choice: it is unconditional. The realms of morality, law and politics are all areas of choice that become applicable after ethics. Under this

\footnotetext{
${ }^{\dagger}$ For an introductory exposition of Heidegger’s argument see: Heidegger, Martin. 1993. Being and Time: Introduction. In Basic Writings: Revised and Expanded Edition, ed. David Farrell Krell, 37-87. London: Routledge.
} 
interpretation, unconditional hospitality may therefore be understood as an irrecusable originary ethics (as the originary ethics), opposed to the conditional hospitality of politics where the dilemmas of choice, limits and finitude arise. Put otherwise, unconditional hospitality refers to a structuring debt to the other at the foundation of human subjectivity; conditional hospitality refers to political hospitality in a visible, empirical sense, at the level of rights, borders, citizenship, and so on. The time comes when one has to choose: when one is faced with more than one ethical demand. This situation is 'the limit of responsibility and the birth of the question: What do I have to do with justice?' (Levinas 1998, 157). This is, in other words, the birth of politics, where unconditional ethical hospitality meets its frontier, and decisions and principles are required within the multiplicity. Therefore, whilst separated and irreducible to each other, ethics and politics may inform one another. As Simon Critchley puts it, '[i]f ethics without politics is empty, then politics without ethics is blind' (Critchley 1999, 283).

Although ethically it is unconditional, one cannot say that at the political level hospitality is always the right choice, because one cannot be hospitable to all. Indeed, Levinas was acutely aware of the harsh reality of politics. In a notorious radio interview, when asked whether the Palestinian is, for the Israeli, the deserving other par excellence, he said the following:

[I]f your neighbour attacks another neighbour or treats him unjustly, what can you do? Then alterity takes on another character, in alterity we can find an enemy, or at least then we are faced with the problem of knowing who is right and who is wrong, who is just and who is unjust. There are people who are wrong. (Levinas $1989,294)$.

Whilst at the heart of humanity is an originary ethics, a subjective welcoming of the other person, this does not negate the necessity of politics in all its coldness and brutality. The issue, then, at the core of this critique, is Derrida's pursuance of hospitality at this political level. Does this not over-simplify the political problematic, revealing a questionable assumption that all people desire (political) hospitality, and that the latter is 
the most appropriate political strategy? Is there a situation in which the ethical demand requires a non-hospitable response at the level of politics? The decline of the nation state and the contemporary prevalence of 'refugees of every kind, immigrants with or without citizenship, exiled or forced from their homes, whether with or without papers' heighten Derrida's interest in hospitality, and helps to justify his preoccupation (Derrida 1999, 71). But this is to characterise the other in a particular way: migratory; stateless and, crucially, seeking a home. Within the context of refugee politics, this is clearly appropriate. But against a generalisation of the category of the other, we pose an alternative exemplar: the other that does not desire hospitality. This alterity is embodied by the person who wants to resist political inclusion. Whilst such an other would necessarily still provoke the unconditional hospitality of originary ethics, it is clear that it is no longer appropriate in their case to promote hospitality at the political level. As David Gauthier has emphasised, a politics of hospitality would presume a universal fraternity, a kinship and co-belonging. And, as he notes, surely the absolute other would be beyond fraternity itself. In this case, then, there can be only two alternatives when hospitality becomes the dominant political imperative:

Either one can remain outside the community, or one can seek to become assimilated into it. In the former instance, the Other remains outside the community's warm embrace. In the latter, the Other is absorbed into the community, and its otherness is eliminated. In both cases, the Other is totalized. (Gauthier 2007, 178).

In other words, the other is either given hospitality that it does not desire, and is therefore assimilated into a fraternity to which it does not belong, or it is left out, which presumably undermines hospitality as a locus for politics. In either case, hospitality reveals its own violence (and we must stress again that by violence we mean ontological violence: the failure of ethics as the reduction of absolute otherness to the language of the same, to whatever extent). 
The critique being made of Derrida here is perhaps one of emphasis. He was undoubtedly aware, as the last section has observed, of the inherent hostility of hospitality. But with this in mind, we ask why he championed it as a political strategy, as well as a mere descriptive account of an originary ethics. When one shifts attention away from the refugee and toward the other who does not desire inclusion, the violence of hospitality is rendered inescapably visible. And to welcome, in this scene, demonstrates a different type of violence, for the failure of hospitality is not that one is not hospitable enough but, paradoxically, that one has been hospitable at all. To welcome, and indeed to say anything, to engage the other in dialogue, is to say too much, to reduce alterity to the sameness of language. This is a violence that cannot be answered fully with the idea of forgiveness, because here forgiveness itself reveals a similar violence: the aspiration to dialogue, and a demand for interaction with an other that prefers to be left alone. Whilst we are told that it is necessary to impose limits, would Derrida go so far to say that conditional hospitality is not merely a requirement to maintain limits and order, but also offers the possibility of judging whether the other wants hospitality in the first place? Whilst he was clearly aware that the scene of forgiveness and hospitality contains its own violence and impossibility, it could be suggested that, in some cases, these are the wrong goals, even as aporias. Forgiveness seeks a bond, a touch, a linguistic recognition and, ultimately, the redemption of the wrong-doer. Might we suggest that in certain situations, such as the quiet provocation of the other that resists inclusion, one cannot honestly seek redemption, but must simply aspire to an impossible and guilty silence?

\section{COUNTER-CRITIQUE}

To recap, at the ethical level the infinite asymmetry between same and other means the other is always demanding and can never be sated. Yet on the political level, where one makes concrete decisions as to how to address the other, the other can cease to demand hospitality. When this happens, unnecessary violence occurs when one offers hospitality to an other that wants nothing of it. But even though the other may cease to demand hospitality, does this mean the other ceases to demand tout court at the political level? If so, this would suggest, contra Derrida, that ethics has ceased to guide politics, amounting 
to a form of politics devoid of ethics, one that would apparently be a more liberating position than to be enchained within a 'fraternity' (a term Derrida has approached cautiously and critically in the past (Derrida 1997b, 138-170)) of which one wants nothing of. In other words, there must be some form of demand made by the other at this political level, lest politics become a banal form of management and calculation, free from the penetrating demand of ethics. The ultimate danger of this position is that it looks suspiciously close to neo-liberal individualism, in which authentic political activity is sacrificed in the name of the market and freedom of (consumer) choice.

This end result, of course, is not our intention. To clarify this we need to focus on the motivating concern of this essay: the infinite debt to the other. A common way to think the relation with the other is to pose the other as transcendent, in a position of absolute alterity. Thus, when it is conceived ontologically it is reduced in a manoeuvre of violent assimilation. This sort of interpretation is commonly associated with Levinas' work." Alternatively, one can conceive the other as transimmanent, a term taken from Jean-Luc Nancy (Nancy 1997, 55). Transimmanence refers to the amorphous line between immanence and transcendence, interiority and exteriority. This line is not only a finite borderline that separates, it is also an infinite lack of infinite separation that exposes the elements of community. In this way, the other elusively distinguishes itself from the same while simultaneously haunting the same from within. This way of thinking alterity can also be attributed to Derrida. For him, community is 'com-mon auto-immunity' or 'autoco-immunity', where the attempt to protect the identity or integrity of community-its

\footnotetext{
* For instance, see the following passage of Adriaan Peperzak's: "The Other...does not fit into my consciousness; it breaks through my circular or elliptic horizon, thus revealing his/her transcendence. As transcendent, the Other responds to the desire that opens my interiority to an absolute exteriority. The Other is, thus, the epiphany of a transcendent otherness or absoluteness" (Peperzak 1997, 32). However, insofar that Levinas believes that the provocation of the other is embedded in the heart of the human subject, he is able to say that the human subject is structured as "the other in the same" (Levinas 1998, 25). What is revealed by this is the manner in which Levinas' philosophy could be considered transimmanent in a manner somewhat different to that found in Nancy's work, separated from the latter by his fierce critique of Heidegger. Such a question goes beyond the scope of this article, however.
} 
immanence - is destructively compromised by the very protection mechanisms it sets up (Derrida 2002, 87). This is because the mechanism that protects the identity of a community through ensuring an ultimate identification with it, must do so by appealing to something more that community. Those willing to die for their country only do so because their country is worth more than life and has a value that transcends its boundaries. At the same time, this appeal to the outside of community in order to maintain its inside creates a gaping hole in the boundary. This boundary thus begins to resemble an invisible force field whose enormous power springs from a transcendent fantasy.

Even more directly, it is clear that Derrida understood the self or the 'one' as violently contaminated by the other:

L'Un se garde de l'autre, The One guards against/keeps some of the other. It protects itself from the other, but, in the movement of this jealous violence, it comprises in itself, thus guarding it, the self-otherness or self-difference (the difference from within oneself) which makes it One. The 'One differing, deferring from itself'. The One as the Other ... . L'Un se fait violence. (Derrida 1995, 78).

This constitution of the self follows the same structure as the constitution of community, that is to say, the self is subject to an auto-immune mechanism where its attempt to protect itself from the other also serves to violently undermine it. The self is a self only because it is in intimate relation with the other, a self which is transimmanently 'one as the other'.

This difference between transcendental separation and the transimmanence of the 'one as the other' has significant implications. For the former, we have an overbearing emphasis on the absolute other at the expense of the 'other as the same'. This emphasis is made in an attempt to protect the other from what we called ontological violence, the reduction of the other to the same. The problem is that in order to do this, we may have ended up creating an excessively transcendental figure in the other that resists inclusion, such that 
nothing one can do, nothing one can say, nothing one can beg, least of all forgiveness, would constitute even a minimally appropriate ethical gesture. There is a sense of ethical paralysis here. Moreover such uncompromised transcendentalism risks mirroring the same excessive ontological violence that we sought to reduce. This is especially so when the only thing that such an other might accept is the murderous death of the 'one' so that it can preserve its peace in isolation.

One 'solution' would be to insist that the ethics of hospitality should remain a purely ethical position and have nothing to do with politics. On the correspondingly pure political level, violence can be minimised through choice. In other words, choosing not to engage with an other who wants nothing of you minimises the political violence towards the other. Hence we can make a distinction between the necessity of ontological violence in the encounter with others and the avoidance of political violence that arises through a matter of choice. But if we separate ethics from politics in this way are we not simply left with the end of authentic political activity mentioned above?

With a transimmanent rather than a transcendental mode of thinking, it is possible to conceive other communities and other 'selves' as exposed to each other. This is a necessary corrective to pure transcendentalism and was a position that Levinas himself was tending towards when he wrote that 'subjectivity is the other in the same' and that this 'subjectivity is the restlessness of the same disturbed by the other' (Levinas 1998, 25). Yet Levinas does not go as far as Derrida, in that Derrida emphasizes not merely the other in the same but also the same as the other (alternatively, one might risk saying that whereas Levinas was preoccupied with the theme of otherwise than Being, Derrida was mindful of the otherwise as Being). This stronger transimmanence helps to shift the focus from the duality of an outside on the inside to the aporia of the infinitely differantiated singularity. It recognises the auto-immunity of the violent relation between singular alterities. This does not lead to an ethics without violence or a pacifist politics, as if one could somehow suspend the violence or struggle upon the encounter with the other, but it 
can call one to responsibility for other 'ones' in a manner that ultimately links the ethical to the political.

While Derrida notes a hiatus in Levinas' thought as regards the link between ethics and politics, he nonetheless conceives this hiatus as a hopeful silence. There can be no classical foundation upon which a determinate content to politics can be deduced from ethics, which is why ethics remains silent about it. Yet this also means that the necessary relation between ethics and politics, from which 'it is necessary to deduce a politics and a law from ethics' is more sophisticated than has hitherto been understood in the classical manner (Derrida 1999, 115). Strictly speaking then, hospitality in this sense is an ethicopolitical gesture that derives from the necessity to combine conditionality with unconditionality, without which hospitality would be an empty and worthless concept. Hospitality welcomes and receives the other as a reflection of the need to begin by responding' (ibid, 24). Instead of prescribing a given content to politics, ethics imputes an infinite responsibility to the political decision, a responsibility that is always a response to the call or the demand of the other. This is why Derrida makes it a necessary ethical injunction at the political level. Where the other demands to be left alone, hospitality can respond by acquiescing to this demand. Saying 'okay' to the other who wants no hospitality is exemplary of hospitality itself. Although such an address to the other reduces its alterity and leads to violence, we must not forget that it is the other that demands to be addressed in the first place. This of course leads to its own violence as Derrida has admitted, but this appears no more violent than the positing of the transcendental other who rejects hospitality. The other never ceases to demand, even when it is a demand for the rejection of hospitality; and in the response to this demand a decision must be taken, informed by a welcoming of the other that is shrouded in perpetual indebtedness, potential violence, and the madness of the unjust encounter.

\section{CONCLUSION}

Across critique and counter-critique, we argue that - whether conceptualised as an ethical or a political demand-hospitality is in some way ineluctable. Like many of Derrida's 
favoured notions, it is structured by aporia. The most immediately striking of these aporias is its dichotomy of conditional and unconditional hospitality, whereby conditional laws are necessary to give effect to unconditional hospitality whilst simultaneously betraying the latter by their limits (Derrida 2000, 77). Both conditional and unconditional hospitality need each other, and are denied by each other. But as well as this, we argue that there is a further aporia, which arises (or perhaps is merely rendered more visible) when hospitality can only be pursued by renouncing itself. There are, we argue, certain situations where the demand placed by the other is, inescapably, for one to desist from hospitality, and as such the unconditional hospitable answer must undo itself. These situations are exemplified by the possibility of the other that does not want inclusion. In this scene, hospitality must directly face its own violence. The first aporia tells us that hospitality is never enough: one can always be more hospitable, and one never truly meets the demand of the other. This self-contradiction and this impossibility reaches its zenith in the second aporia, which manifests when hospitality must deny itself. This is the absolute limit point of hospitality's self-contradiction, where it must not only recognise the residue of violence that is necessitated by its structural impossibility, but furthermore, it is revealed to be violence itself. This would be to conceive of the political situation where hospitality and violence become indistinguishable.

Derrida takes a position that is in one sense the inverse of Kant's. Whereas Kant held that the natural situation is one of war, and that law is required to institute peace, Derrida holds that peace, as the pacifistic welcoming of the other, is the originary relation. However, even war and violence must still presuppose and bear the trace of hospitality (Derrida 1999, 90); and politics, even when unavoidably brutal, is still guided by ethics. Similarly, in Politics of Friendship, Derrida counsels the reader that in the field of the political, 'the enemy can hate or wage war on me in the name of friendship, for Friendship's sake, out of friendship for friendship' (Derrida 1997b, 72). In other words, against the tradition of political theory exemplified by Carl Schmitt, enmity is not the irreducible determinant of the political. Rather, it is one particular strategy or effect, built upon the true foundation: the possibility of friendship. In a similar vein, we suggest that 
in the name of hospitality, obligated by the unconditional demand to respond and to be responsible, one must, if the situation demands, refuse hospitality. This renunciation is, predictably by now, impossible. The effect is that hospitality becomes its own torsion, turning itself inside out, attempting to disavow itself for the sake of itself. One is here reminded of Levinas' account of ethical subjectivity, toward which Derrida paid no small amount of admiration in the development of his notion of hospitality. Levinas tells us that the subject is both constituted and undone in the relation with the other because, paradoxically, only a separated being can exist for the other. In this contradictory constitution of the subject, as the 'anguish of contraction and breakup' (Levinas 1998, 108), the 'contraction' signifies a 'recurrence to oneself out of an irrecusable exigency of the other' (ibid, 109). Does this not indicate that ethics or hospitality cannot be pure devotion or welcoming, and that they require, or require the recognition of, separation? Just as the autonomous egotic self must undo itself in identification of its debt to the other, so too the absolutely selfless gesture of heteronomous hospitality must undo it'self', signalling the return to the self.

Conveniently, the production of this article serves as something of a performative metaphor of the argument with which we conclude. This piece was (thankfully) not born out of consensus, but a productive debate that, we hope, has continued without being reconciled in its committal from words to paper. This process of writing has, we realise, raised many of the dilemmas of borders and hospitality that we have discussed substantively. How, for example, do two authors say some-thing without assimilation, and so without becoming one singular author? In other words, how do we articulate a point or an argument whilst still retaining our independent authorship? Co-authorship occurs at the threshold between, on the one hand, absolute separation, and on the other hand, absolute consensus or assimilation. In the same way that Kant conceived the world as a finite globe that we must share as members of a grand cosmopolitical constellation, this essay represents a more modest finite space, a microcosm that two authors inhabit. In openly confronting each other within a single work, a dissensus has been exposed that may not have been so palpable if there had been a statement of positions in two independent contributions. Here we hope we have demonstrated the necessity to address 
each other as each other's other, being forced to respond in virtue of the ineluctable exigency of hospitality. And here, quite clearly, the violence of hospitality shows itself. For each of us must bear each other, respond to each, and in doing so hospitality demands that we interpret each other and influence each other, integrating each other's thought into our own, and vice versa. This must occur even in the most sympathetic of dialogues. At the same time, in order to ensure a genuine co-authorship (the co-authenticity of a signature that is either the two within one or the two as one) we must seek, to some extent, to retain our separation and forgive each other, as far as possible, for the violence we have inescapably inflicted. But to say that this piece has been written out of dissensus is hopefully not to undermine the meaning it carries. We may be so bold as to suggest that we have merely replicated the torsion at the heart of all writing, even in that of the most solitary author. For all writing not only presupposes a reader, but is demanded by this reader, who has provoked the author into action. Writing, no less at the service of originary ethics than any other aspect of human activity, begins with hospitality, with the ineluctable indebtedness one holds towards the other, and the demand to respond. In the situation we find ourselves in, the time comes when the most hospitable response is to reject hospitality in the name of hospitality, and to maintain or even reinstate division, and therefore to allow the co-author to continue to be an author. We, the co-authors, must nonetheless end by signing. And in so doing, it is the grammatical 'we' who sign in the first person plural, as much as the ethical 'we' who sign as, first, persons plural.

\section{REFERENCES}

Caputo, John D. 1997. Deconstruction in a nutshell: A Conversation with Jacques Derrida. New York: Fordham University Press.

Critchley, Simon. 1999. Ethics, Politics, Subjectivity: Essays on Derrida, Levinas and Contemporary French Thought. London: Verso.

Derrida, Jacques. 1995. Archive Fever. Chicago: University of Chicago Press.

Derrida, Jacques. 1997a. Il n'y a pas de culture ni de lien social sans un principe d'hospitalité. Le Monde. http://www.jacquesderrida.com.ar/frances/hospitalite.htm. Accessed 14 June 2008.

Derrida, Jacques. 1997b. The Politics of Friendship. London: Verso.

Derrida, Jacques. 1999. Adieu to Emmanuel Levinas. Stanford: Stanford University Press. 
Law and Critique (2009) vol. 20 no. 2, 193-206.

The final publication is available at www.springerlink.com

Derrida, Jacques. 2000. Of Hospitality. Stanford: Stanford University Press.

Derrida, Jacques. 2002. Acts of Religion. London: Routledge.

Derrida, Jacques. 2001. On Cosmopolitanism and Forgiveness. London: Routledge.

Gauthier, David. 2007. Levinas and the Politics of Hospitality. History of Political Thought 28(1): 158-180.

Kant, Immanuel. 1970. Perpetual Peace. In Kant's Political Writings, ed. Hans Reiss, 93-130. Cambridge: Cambridge University Press.

Levinas, Emmanuel. 1969. Totality and Infinity: An Essay on Exteriority. Pittsburgh: Duquesne University Press.

Levinas, Emmanuel. 1989. Ethics and Politics. In The Levinas Reader, ed. Sean Hand, 289-297. Oxford: Blackwell.

Levinas, Emmanuel. 1998. Otherwise than Being or Beyond Essence. Pittsburgh: Duquesne University Press.

Nancy, Jean-Luc. 1997. The Sense of the World. Minneapolis: University of Minnesota Press.

Peperzak, Adriaan. 1997. Beyond: The Philosophy of Emmanuel Levinas. Evanston: Northwestern University Press. 